\title{
ANALISIS PERMOHONAN PENDAFTARAN MEREK SECARA INTERNASIONAL BAGI UMKM SETELAH DITERBITKAN PERATURAN PRESIDEN NO. 92 TAHUN 2017 TENTANG RATIFIKASI PROTOKOL MADRID
}

\section{Yohanes Adi Putra Mahardika, Irna Nurhayati}

Universitas Gadjah Mada Yogyakarta

Contact: yohanesadiputra.sh@gmail.com; irnafh@gmail.com

Diterima: 28 Juni 2019

Direvisi: 29 Juni 2019

Disetujui: 5 Agustus 2019

Hak Cipta: (C)2019

Halaman: 1-13

\begin{abstract}
This research aims to analyze the barriers to the application of international trademark registration for MSME after the issuance of Presidential Regulation No. 92 of 2017 concerning Ratification of Madrid Protocols. Another purpose of this research is to find out the government's efforts in facing obstacles to international brand registration applications for MSMEs.This research is a normative legal research using primary data and secondary data. Primary data was collected through interviews with the guidelines of the interview, while secondary data obtained through the method of documentation with a study of the documentation and data analysis done qualitatively.The results of this study are: First, there are obstacles to the application of international trademark registration for MSMEs after the issuance of Presidential Regulation No. 92 of 2017 concerning the Ratification of the Madrid Protocol because of the lack of interest and insight of MSMEs on international trademark registration applications, general regulations, language difficulties, and the cost of expensive brand registration applications. Second, the efforts made by the government to face obstacles for MSMEs are by making rules for reducing the cost of applying for basic brand registration, the existence of a special team of the Madrid Protocol and increasing socialization of brands and applications for trademark registration using the Madrid Protocol.
\end{abstract}

Keywords: Trademark registration, international trademark, Madrid Protocol, MSMEs 


\section{PENDAHULUAN}

Pelaku usaha perlu melakukan pendaftaran merek, khususnya pelaku usaha mikro, kecil, menengah (UMKM) dalam mengembangkan usaha miliknya, menghadapi pasar bebas dan mendapatkan perlindungan hukum. Merek tersebut juga menjadi daya pembeda antara barang atau jasa hasil produksinya dengan barang atau jasa hasil produksi pelaku usaha lainnya yang berasal dari dalam maupun dari luar negeri yang ada dalam perdagangan, serta sebagai sarana untuk menghindari sengketa merek atau plagiasi merek oleh pihak lain. Perlindungan hukum yang diperoleh melalui pendaftaran ini menggunakan sistem konstitutif dengan menganut asas pendaftar pertama (first to file). Melalui asas ini, pihak yang mendaftarkan mereknya terlebih dahulu dianggap sebagai pemilik merek yang sah (Utomo, 2010). Instansi yang bertugas dalam hal pendaftaran merek di Indonesia adalah Direktorat Jenderal Kekayaan Intelektual (DJKI) yang berada dalam naungan Kementerian Hukum dan Hak Asas Manusia.

Perlindungan hukum terhadap merek di luar negeri juga dilakukan dengan cara pendaftaran merek tersebut di negara tujuan. Article 3 Madrid Protocol mengenai permohonan internasional mengatur bahwa setiap permohonan internasional berdasarkan Protokol Madrid disajikan dalam formulir yang telah ditentukan oleh Peraturan-Peraturan. Kantor asal yang menyatakan bahwa keterangan yang ada dalam permohonan internasional sesuai dengan keterangan yang ada dalam sertifikat, dalam permohonan dasar, atau pendaftaran dasar. Indonesia resmi menjadi negara anggota Protokol Madrid dan telah menjadi anggota ke-100 yang disampaikan dalam sidang umum World Intellectual property Organization (WIPO) ke-57 di Jenewa (Lihat: http://kabar24.bisnis.com/read/2017100 3/16/695579/ini-dampak- protokolmadrid-bagi-konsultan-pemilik-merek,). Tanda bahwa Indonesia menjadi anggota Protokol Madrid ditunjukkan dengan meratifikasi Protokol Madrid melalui Peraturan Presiden No. 92 Tahun 2017. Protokol Madrid adalah suatu sistem pendaftaran merek internasional yang memfasilitasi pemilik merek dari suatu negara untuk mendapatkan perlindungan atas mereknya di negara lain melalui pendaftaran merek tersebut pada sekretariat yang ditunjuk (Nurhayati, \& Merdekawati, 2008).

Undang-Undang No. 20 Tahun 2016 tentang Merek dan Indikasi Geografis (UU Merek) mengatur mengenai permohonan pendaftaran merek internasional mengenai bentuk dan siapa yang dapat mengajukan permohonan pendaftaran merek. Aturan tersebut diperkuat dengan adanya Peraturan Pemerintah Nomor 22 Tahun 2018 tentang Pendaftaran Merek Internasional Berdasarkan Protokol Terkait dengan Persetujuan Madrid Mengenai Pendaftaran Merek Secara Internasional sebagai bentuk untuk melaksanakan ketentuan Pasal 52 ayat (4) UU Merek. Hal yang menjadi persoalan dalam Peraturan Pemerintah Nomor 22 Tahun 2018 tentang Pendaftaran Merek Internasional Berdasarkan Protokol.

Terkait dengan Persetujuan Madrid Mengenai Pendaftaran Merek Secara Internasional yang selanjutnya disebut PP No. 22 Tahun 2018 hanya memberikan pengaturan mengenai pendaftaran merek internasional berdasarkan Protokol Madrid bagi pelaku usaha secara umum, belum memberikan kemudahan bagi UMKM sebagai pemilik merek untuk mendaftarkan mereknya secara internasioal di negara- 
negara yang meratifikasi Protokol Madrid seperti program Nawa Cita yang dikeluarkan oleh Pemerintah dalam mendukung kemajuan UMKM agar dapat bersaing secara internasional.

Problematik hukum selanjutya adalah syarat-syarat untuk mendaftarkan merek melalui Protokol Madrid. Syarat yang perlu dipenuhi oleh pemohon sebelum mengajukan merek internasionalnya, diantaranya adalah pemohon sudah memiliki merek terdaftar di DJKI atau sedang dalam pengajuan permohonan pendaftaran

(Lihat:

http://www.dgip.go.id/sosialisasipendaftaran-merek-internasional-madridprotocol). Hal ini menjadi dilema bagi UMKM karena masih banyak produk UMKM yang dipasarkan secara online maupun offline belum mendaftarkan merek miliknya

(https://www.ukmindonesia.id/baca-

artikel/95). Problematik yang ada mengakibatkan Permohonan merek melalui Protokol Madrid di Indonesia sejak Januari 2018 masih sedikit. Sampai saat ini, jumlah yang tercatat baru sebanyak 14 permohonan merek. Sedangkan permohonan merek yang berasal dari luar negeri yang masuk ke Indonesia cukup banyak

https://kumparan.com/media-centerkementerian-hukum-dan-ham/ukmdaftarkan-merek-ke-luar-negeri-sistemprotokol-madrid-masih-sunyi 27431110790549847).

Rendahnya minat UMKM untuk mendaftarkan mereknya dikhawatirkan menimbulkan sengketa di kemudian hari. Seperti kejadian 10 Tahun silam dalam kasus Kopi Gayo dan Kopi Toraja. Merek kopi Gayo dan kopi Toraja ternyata sudah didaftarkan oleh pengusaha Belanda dan Jepang, sehingga petani di Indonesia tidak bisa mengekspor kedua jenis komoditas tersebut dengan nama kopi Gayo atau Toraja (Lihat: https:// nasional.kompas.com/read/2008/05/28/1 $5421243 /$ paten. kopi. gayo. milik. belanda. toraja. Milik. jepang) kopi. gayo. milik. belanda. toraja. Milik. jepang). Menyadari urgensi pendaftaran merek internasional, syarat pendaftaran merek internasional dan hal apa saja yang mengakibatkan merek internasional tidak dapat didaftarkan tersebut, perlu suatu upaya yang dapat merambah bagian terkecil dari masyarakat yang masih awam mengenai hal tersebut khususnya UMKM. Pemerintah sadar bahwa sebenarnya sektor UMKM dapat menopang ketahanan ekonomi nasional.

Berdasarkan hal di atas dapat terlihat adanya hambatan bagi pelaku UMKM dalam pendaftaran merek melalui Prokol Madrid. Maka dari itu, penulis memilih topik penelitian hukum dengan judul Analisis Permohonan Pendaftaran Merek Secara Internasional Bagi UMKM Setelah diterbitkan Peraturan Presiden No. 92 Tahun 2017 tentang Ratifikasi Protokol Madrid.

\section{METODOLOGI PENELITIAN}

Jenis penelitian yang dilakukan adalah penelitian hukum normatif dan lebih mengutamakan pada Penelitian Kepustakaan (Library Research) untuk memperoleh data sekunder untuk mengumpulkan sejumlah data meliputi bahan pustaka yang bersumber dari bukubuku (Sumardjono \& Maria, 2014).

Cara pengumpulan data dalam penelitian ini adalah studi dokumenter dan wawancara ke lokasi penelitian untuk mendapatkan data primer. Wawancara merupakan cara yang digunakan untuk memperoleh keterangan secara lisan yang bertujuan untuk mengumpulkan 
keterangan tentang kehidupan manusia serta pendapat-pendapat dari narasumber (Sumardjono \& Maria, 2014). Cara ini dipilih mengingat bahwa penelitian ini memerlukan penelitian lapangan (field research) untuk memperoleh data primer (Azwar, 1998).

Penelitian ini mengolah data menggunakan metode penelitian yang bersifatdeskriptif analitis, analisis data yang dipergunakan adalah pendekatan kualitatif terhadap data primer dan data sekunder (Ali, 2009). Penelitian ini menggunakan analisis data kualitatif yang lebih menekankan analisisnya pada proses penyimpulan deduktif dan induktif serta pada dinamika hubungan antar fenomena yang diamati dengan menggunakan logika ilmiah.

\section{HASIL DAN PEMBAHASAN}

\section{Hambatan Permohonan Pendaftaran Merek Secara Internasional Bagi UMKM Setelah Diterbitkan Peraturan Presiden No. 92 Tahun 2017 Tentang Pengesahan Protokol Madrid.}

Permohonan pendaftaran merek secara internasional masih terdapat hambatanhambatan bagi pelaku UMKM. Hambatanhambatan tersebut antara lain :

1. Hambatan Sosiologis

Adapun hambatan sosiologis yang ada, yaitu:

a. Minat UMKM dalam Pendaftaran Merek Berdasarkan hasil wawancara dengan Isabella Yudha Hastarini, Owner Denz Kitchen \& Tix Kitchen Project, mengungkapkan bahwa belum mendaftarkan merek karena belum terpikirkan untuk mendaftarkan merek karena lebih fokus untuk mengembangkan usaha miliknya lebih dahulu. Isabella belum mengetahui adanya mekanisme permohonan pendaftaran merek secara internasional dengan Protokol Madrid (Wawancara dengan Isabella Yudha Hastarini,28 September 2018). Wawancara lain yang dilakukan penulis adalah dengan Afif Dhawy, Owner Sanproject, Afif juga belum mendaftarkan merek karena beranggapan bahwa merek adalah hal kedua yang perlu dilakukan karena hal yang lebih penting adalah pengembangan usaha terlebih dahulu dan tidak mengetahui mengenai permohonan merek secara internasional menggunakan Protokol Madrid (Wawancara dengan Afif Dhawy, 25 September 2018).

Berdasarkan hal yang telah diutarakan di atas, pelaksanaan pendaftaran merek melalui Protokol Madrid di kalangan UMKM terdapat kecenderungan kurangnya minat dalam pendaftaran merek. Hal demikian juga diperkuat oleh Budi Agus Riswandi dimana budaya pelaku UMKM untuk mendaftarkan merek miliknya masih tergolong lemah (Wawancara dengan Budi Agus Riswandi, 25 Oktober 2018).

b. Kurangnya Sosialisasi UMKM

Pelaksanaan pendaftaran merek melalui protokol madrid belum diketahui di kalangan UMKM. Hal ini disebabkan pelaku UMKM tidak masuk dalam anggota komunitas UMKM sehingga tidak mengikuti sosialisasi yang diadakan oleh pemerintah (Wawancara dengan Arief Setiawan, 25 Oktober 2018). Hal ini sesuai dengan wawancara yang dilakukan penulis dengan Afif Dhawy, Owner Sanproject dan Isabella Yudha Hastarini, Owner Denz Kitchen \& Tix Kitchen Project yang masih tidak mengetahui bagaimana proses mendaftarkan merek miliknyaBerdasarkan hasil wawancara dengan Sri Hadi Waluyo, Owner Zianturi Guitar, usaha yang 
penjualannya telah merambah hingga ke luar negeri seperti Oakland dan Inggris. Saat itu, Sri Hadi telah mendaftarkan mereknya atas tawaran dari Departemen Industri. Sri Hadi pada mulanya tidak mengetahui mengenai pendaftaran merek ini, hanya saja tawaran dari Departemen Industri membuka jalan pemikiran Sri Hadi untuk mendaftarkan merek dan mendistribusikannya hingga ke luar negeri (Wawancara dengan Sri Hadi Waluyo, 5 September 2018). Dapat dilihat bahwa pemikiran dari UMKM akan terbuka jika terdapat informasi yang relevan dan bantuan realisasi dari Pemerintah. Hal ini disebabkan pengetahuan awam masyarakat yang tidak mengikuti perkembangan hukum yang dinamis dari waktu ke waktu. Bagi perusahaan besar, hal seperti pendaftaran merek khususnya pendaftaran merek secara internasional menggunakan Protokol Madrid bisa jadi hal mudah akan tetapi bagi pelaku UMKM hal semudah ini belum terpikirkan karena dangkalnya pengetahuan.

\section{Hambatan Yuridis}

Saat ini, pemerintah Indonesia telah meratifikasi Protokol Madrid dengan Peraturan Presiden No. 92 Tahun 2017 tentang Ratifikasi Protokol Madrid sebagai bentuk menjalankan amanat Pasal 52 ayat (4) Undang-Undang No. 20 Tahun 2016 tentang Merek dan Indikasi Geografis (UU Merek). Kemudian terdapat PP No. 22 Tahun 2018 tentang Pendaftaran Merek Internasional Berdasarkan Protokol Terkait dengan Persetujuan Madrid dengan Persetujuan Madrid Mengenai Pendaftaran Merek Secara Internasional. Dalam aturanaturan tersebut diatur mengenai subyek dan tata cara pendaftaran merek secara internasional. Menurut wawancara penulis dengan Rasyid Kurniawan, Staff Sub Bidang
AHU dan HKI, Kantor Wilayah Kementerian Hukum dan HAM Daerah Istimewa Yogyakarta, aturan-aturan tersebut masih umum, belum ada aturan khusus yang memberi kemudahan bagi pelaku UMKM yang menjadi pemohon pendaftaran merek secara internasional (Wawancara dengan Rasyid Kurniawan, 3 November 2018).

Terdapat pula syarat pokok agar merek dapat diajukan oleh pemohon pendaftaran merek secara internasional melalui Protokol Madrid. Syarat tersebut adalah harus adanya merek nasional sebagai merek dasar yang telah didaftarkan di negara asal (Wawancara dengan Rasyid Kurniawan, 3 November 2018). Selain itu, dalam Pasal 3 Protokol Madrid mengatur pemohon pendaftaran merek secara internasional menggunakan Protokol Madrid untuk mencantumkan kelas barang dan jasa yang akan didaftarkan sesuai dengan klasifikasi Nice Agreement. Isabella Yudha Hastarini, Owner Denz Kitchen \& Tix Kitchen juga belum mengetahui mengenai kelas klasifikasi barang dan jasa sesuai dengan Nice Agreement, hal senada juga diungkapkan oleh Berend Abiyoso, Owner MAVAZI \& Co dan juga Afif Dhawy, Owner Sanproject. Berbeda dengan Lidwina Wuri, Owner Zola.id yang telah mendaftarkan merek miliknya secara nasional menggunakan jasa pendaftaran merek. Lidwina melengkapi syarat-syarat yang dibutuhkan dalam pendaftaran merek dengan dibantu oleh jasa pendaftaran merek sehingga dirinya akan menyiapkan apa yang dibutuhkan sebagai syarat atau hal tambahan untuk memenuhi syarat tersebut (Wawancara dengan Lidwina Wuri, 21 September 2018).

Hambatan lainnya dalam pendaftaran merek internasional bagi UMKM adalah rasa kurang percaya UMKM terhadap perlindungan hukum yang diberikan setelah merek miliknya didaftarkan. Hal ini 
karena perlindungan hukum terhadap merek terdaftar masih lemah karena masih terjadi kasus terkait pemalsuan merek (Wawancara dengan Arief Setiawan, 25 Oktober 2018).

\section{Hambatan Teknis}

Adapun hambatan teknis yang dihadapi, yaitu (Wawancara dengan Arief Setiawan, 25 Oktober 2018):

a. Bahasa yang digunakan dalam Protokol Madrid

Bahasa yang digunakan untuk mendaftarkan melalui Protokol Madrid telah ditentukan dengan menggunakan bahasa Perancis, bahasa Spanyol dan bahasa Inggirs. Hal ini menyebabkan UMKM ragu-ragu dalam mendaftarkan merek internasional menggunakan Protokol Madrid karena keterbatasan kemampuan UMKM dalam berbahasa asing. Keterbatasan berbahasa ini berdampak dalam menjelaskan kriteria merek UMKM yang akan didaftarkan sehingga rawan terjadi kesalahan dalam penjelasan merek yang akan didaftarkan tersebut (Wawancara dengan Arief Setiawan, 27 Oktober 2018).

b. Waktu pendaftaran yang lama

UMKM merasa waktu pengurusan pendaftaran merek internasional dirasa sampai sertifikat hak merek sangat lama. Hal ini dirasakan oleh Lidwina Wuri, Owner Zola.id yang telah mendaftarkan merek miliknya dan menunggu cukup lama sampai sertifikat hak merek miliknya jadi. Hal ini membuat dilema UMKM dalam mendaftarkan merek miliknya menggunakan Protokol Madrid karena merasa waktu pendaftaran merek internasional ini akan memakan waktu yang lebih lama dari pendaftaran merek nasional (Wawancara dengan Arief Setiawan, 27 Oktober 2018).

\section{Hambatan Ekonomis}

Hambatan ekonomis berupa kekhawatiran biaya pendaftaran oleh UMKM. Biaya yang dibayarkan sehubungan dengan aplikasi untuk pendaftaran internasional di bawah Sistem Madrid terdiri dari: biaya dasar; biaya tambahan untuk masing-masing Pihak yang ditunjuk; dan biaya tambahan untuk setiap kelas barang dan jasa ( Lihat: http:// www. wipo. int/ finance/ en/madrid. html,). Pendaftaran merek internasional membutuhkan merek dasar yang telah didaftarkan atau sedang didaftarkan di Negara asal pendaftaran merek (Wawancara dengan Rasyid Kurniawan, 3 November 2018). Hal inimenimbulkan biaya cukup besar yang harus dikeluarkan oleh pelaku UMKM dalam mendaftarkan merek miliknya. Setidaknya ada dua jenis biaya yang harus dikeluarkan pengusaha untuk mendaftarkan merek secara internasional menggunakan Protokol Madrid, yaitu basic fee dan individual fee. Biaya pendaftaran merek dagang internasional menggunakan mata uang franc Swiss (Chf). Untuk biaya dasar,biayanya adalah 653 franc Swiss (sekitar Rp. 9.239.000,00) atau 903 franc Swiss (sekitar Rp. 13.160.300,00) untuk tanda berwarna, ditambah biaya administrasi tergantung dimana pelaku usaha atau pemilik merek ingin melindungi mereknya (Wawancara dengan Rasyid Kurniawan, 3 November 2018).

Memang ada lembaga-lembaga yang memberikan program bantuan kepada UMKM seperti Lembaga Pengelola Dana Bergulir (LPDB) - Koperasi Dan Usaha Mikro, Kecil dan Menengah (KUMKM) yang merupakan Satuan Kerja di lingkungan Kementerian Koperasi dan UKM RI serta Badan Ekonomi Kreatif (Bekraf) (Lihat: http://www.bekraf.go.id/berita/page/10/ 76-penandatanganan-perjanjian-kerja- 
sama-badan-ekonomi-kreatif-bekrafdengan-lembaga-pengelola-dana- bergulirkoperasi-dan-usaha-mikro-kecil-danmenengah-lpdb-kumkm).

Lembaga-lembaga ini memiliki program untuk meningkatkan produk UMKM, program pengembangan produk dan pemasaran, termasuk program dalam fasilitas pendaftaran merek bagi UMKM. Namun program-program ini dirasa belum menyeluruh dan belum mencakup pembiayaan mengenai pendaftaran merek khususnya merek internasional (Wawancara dengan Lidwina Wuri, 21 September 2018). Akibatnya biaya yang ditimbulkan untuk mendaftarkan merek internasional dirasakan masih cukup mahal bagi pelaku UMKM yang akan mendaftarkan merek internasional miliknya.

\section{Upaya Pemerintah Mengatasi Hambatan Permohonan Pendaftaran Merek Secara Internasional Bagi UMKM Setelah Diterbitkan Peraturan Presiden No. 92 Tahun 2017 Tentang Pengesahan Protokol Madrid.}

Sebagai bentuk mewujudkan pengembangan UMKM dan mengatasi hambatan permohonan pendaftaran merek secara internasional bagi UMKM setelah diterbitkan Peraturan Presiden No. 92 Tahun 2017 tentang Ratifikasi Protokol Madrid, maka upaya-upaya yang dilakukan pemerintah adalah sebagai berikut :

\section{Upaya Normatif}

Dalam upaya mengatasi hambatan permohonan pendaftaran merek secara internasion, Indonesia menjadi anggota Protokol Madrid dan telah meratifikasi Protokol Madrid melalui Peraturan Presiden No. 92 Tahun 2017 tentang Pengesahan Protokol Madrid. Protokol ini memiliki beberapa hal yang dianggap merupakan keuntungan atau kemudahan yang diberikan, antara lain melalui satu aplikasi pendaftaran yang masuk untuk sejumlah negara anggota Protokol Madrid dengan hanya menggunakan Bahasa yang telah ditentukan dalam Protokol Madrid, serta hanya melewati satu kali pemeriksaan. formal dan satu kali pengumuman bagi sejumlah negara, pada intinya membuat biaya untuk pendaftaran merek internasional dapat lebih efektif dan efisien (Suryomurcito, 2007)

Upaya pemerintah untuk menanggulangi hambatan mengenai biaya pendaftaran merek secara internasional adalah berupa peringanan pendaftaran merek dasar yang menjadi syarat agar merek milik UMKM dapat didaftarkan melalui Protokol Madrid (Wawancara dengan Rasyid Kurniawan, 3 November 2018). Pemerintah mengeluarkan Peraturan Pemerintah Nomor 45 Tahun 2016 Tentang Perubahan Kedua atas Peraturan Pemerintah Nomor 45 Tahun 2014 Tentang Jenis Dan Tarif Atas Jenis Penerimaan Negara Bukan Pajak, diatur pendaftaran merek bagi UMKM lebih murah dibandingkan pendaftaran merek yang dilakukan oleh pelaku usaha Non UMKM.

Pemerintah juga melakukan kerjasama antara Kementerian Hukum dan Ham dengan Kementerian Koperasi dan Usaha Kecil dan Menengah serta Badan Ekonomi Kreatif dalam hal pinjaman/pembiayaan dana bergulir dalam rangka dukungan permodalan bagi UMKM (Lihat: http://www.bekraf.go.id/berita/page/10/ 76-penandatanganan-perjanjian-kerjasama-badan-ekonomi-kreatif-bekrafdengan-lembaga-pengelola-dana- bergulirkoperasi-dan-usaha-mikro-kecil-danmenengah-lpdb-kumkm). Namun hal ini dirasa masih kurang karena bantuan pengurangan biaya hanya diberikan untuk pendaftaran merek secara nasional 
sebagai merek dasar yang akan digunakan sebagai syarat mendaftarkan merek internasional melalui Protokol Madrid yang cukup mahal bagi UMKM. Kemudahan lainnya yang diberikan pemerintah bagi UMKM dalam Pendaftaran Merek Internasional adalah Merek Kolektif. Pada dasarnya merek kolektif ini dapat diinisiasi oleh sekelompok orang, komunitas dan pemerintah, sehingga biaya pendaftaran bisa ditanggung bersama. Namun karena pemiliki merek adalah banyak orang, sehingga sulit untuk menjaga standarisasi produk dan rawan terjadi perselisihan antar anggota pemilik merek yang mendaftarkan dengan merek kolektif (Wawancara dengan Rasyid Kurniawan, 3 November 2018).

Untuk kemudahan yang diberikan oleh Pemerintah perihal bahasa yang digunakan dalam permohonan pendaftaran merek secara internasional menggunakan Protokol Madrid, Pemerintah membuat kebijakan di dalam lingkungan Kementerian Hukum dan HAM mengenai tim khusus yang bertugas untuk membantu pengusaha dalam mendaftarkan merek secara internasional menggunakan Protokol Madrid (Wawancara dengan Rasyid Kurniawan, 3 November 2018). Dalam Pasal 16 Protokol Madrid juga mengatur bahwa Biro Internasional akan menterjemahkan bahasa jika ada bahasa yang tidak pas dengan memanggil pemohon. Perihal perlindungan hukum terhadap merek internasional yang didaftarkan melalui Protokol madrid ditentukan berdasarkan hasil pemeriksaan subtantif yang disesuaikan dengan undangundang nasional negara tujuan. Indonesia sendiri memberikan perlindungan terhadap merek internasional berdasarkan Undang-Undang Nomor 20 Tahun 2016 tentang Merek dan Indikasi Geografis.

\section{Upaya Subtantif}

Hukum tidak hanya sebagai alat pengendalian saja tapi juga sebagai pegangan dan pengendali social (Adi, 2012). Dengan adanya perlindungan hukum terhadap Hak Kekayaan Intelektual bagi pelaku usaha UMKM akan memberikan pengembangan bagi industri kreatif dalam mengembangkan produknya dan pemasaran produk tersebut (Wawancara dengan Arief Setiawan, 25 Oktober 2018).

Hak atas Merek merupakan hak eksklusif yang bersifat khusus dan hanya dimiliki oleh orang yang terkait langsung dengan kekayaan intelektual yang dihasilkan. Hal senada juga dijabarkan oleh Budi Agus Riswandi, Konsultan Hak Kekayaan Intelektual yang menjabarkan bahwa hak ekslusif sebagai hak yang dimiliki oleh pemegang hak merek untuk menggunakan merek miliknya atau melarang pihak lain untuk menggunakan merek tersebut.

Perjanjian Madrid (Madrid Agreement) merupakan cerminan persetujuan internasional yang bertujuan memberikan perlindungan merek secara internasional. Perlindungan diberikan secara sederhana bagi pemilik merek terdaftar di suatu negara anggota dengan mengajukan pendaftaran secara internasional melalui Persatuan Internasional Biro HKI (The Uniterd International Bureaux for the Protection of Intellectual Property/BIRPI) berdasarkan satu biaya dan tidak adanya penolakan dari setiap kantor HKI nasional dalam waktu yang telah ditentukan (Jened, 2013).

Perlindungan hukum sendiri terbagi menjadi 2 (dua), yaitu perlindungan secara preventif dan perlindungan secara represif, yaitu :

a. Perlindungan Preventif

Perlindungan hukum yang preventif 
bertujuan untuk mencegah terjadinya sengketa, yang mengarahkan tindakan pemerintah bersikap hati-hati dalam pengambilan keputusan berdasarkan diskresi (Alfons, 2010).

1) Perlindungan Hukum Terhadap Merek

Berdasarkan Pendaftaran Internasional Perlindungan hukum terhadap Merek berdasarkan Pendaftaran Internasional diberikan selama 10 (sepuluh) tahun sejak Tanggal Pendaftaran Pendaftaran Internasional. Perlindungan hukum terhadap Merek berdasarkan Pendaftaran Internasional ini dapat dilakukan perpanjangan dalam jangka waktu berdasarkan ketentuan Peraturan Umum. Namun, dengan adanya Protokol Madrid tidak serta merta memberikan perlindungan bagi pemilik merek terhadap merek miliknya karena perlindungan akan terjadi atau diberikan jika merek tersebut telah didaftarkan dan pemegang hak atas merek tersebut juga turut serta dalam pengawasan atas merek miliknya agar tidak digunakan oleh pihak lain.

2) Badan yang Melindungi

Badan yang melindungi adalah negara dimana merek tersebut didaftarkan dan perlindungan hukum yang diberikan negara tersebut sesuai dengan peraturanperaturan yang berlaku di masingmasing negara dimana merek itu terdaftar (Wawancara dengan Budi Agus Riswandi, 21 Oktober 2018).

3) Hak pemegang merek

Hak bagi pemegang merek dilindungi oleh undang-undang karena hak merek pada hakikatnya merupakan hak yang memiliki karakteristik khusus yang diberikan oleh negara kepada yang berhak sesuai dengan prosedur dan syaratsyarat yang harus dipenuhi (Hartono, 1993). Hak pemegang merek terdiri atas hak moral dan hak ekonomi. Hak moral adalah hak pemegang merek untuk diakui haknya sebagai pemegang merek yang sah. Hak ekonomi merupakan hak eksklusif Pemegang Merek untuk mendapatkan manfaat ekonomi atas mereknya. Hak moral tidak dapat dialihkan selama Pemegang Merek masih hidup, tetapi pelaksanaan hak tersebut dapat dialihkan dengan wasiat atau sebab lain sesuai dengan ketentuan peraturan perundang-undangan setelah Pemegang Merek meninggal dunia.Hak Merek dapat beralih atau dialihkan, baik seluruh maupun sebagian karena pewarisan, hibah, wakaf, wasiat, perjanjian tertulis, atau sebab lain yang dibenarkan sesuai dengan ketentuan peraturan perundang- undangan.

4) Perjanjian lisensi

Menurut Pasal 1 angka 18 UU Merek disebutkan bahwa Lisensi adalah izin yang diberikan oleh pemilik Merek terdaftar kepada pihak lain berdasarkan perjanjian secara tertulis sesuai peraturan perundang-undangan untuk menggunakan Merek terdaftar. Dalam Pasal 24 PP No. 22 Tahun 2018 tentang Pendaftaran Merek Internasional Berdasarkan Protokol Terkait dengan Persetujuan Madrid dengan Persetujuan Madrid Mengenai Pendaftaran Merek Secara Internasional, Merek berdasarkan Pendaftaran Internasional dapat dilakukan pencatatan lisensi yang didapatkan melalui permohonan pencatatan lisensi yang diajukan secara tertulis kepada Menteri dengan dikenai biaya. 
Pasal 42 UU Merek mengatur bahwa Pemilik Merek terdaftar dapat memberikan Lisensi kepada pihak lain untuk menggunaka Merek tersebut baik sebagian maupun seluruh jenis barang dan/atau jasa. Perjanjian Lisensi wajib dimohonkan pencatatannya dan untuk merek internasional harus dimohonkan pencatatan di Biro Internasional dalam formulir resmi yang sesuai oleh pemilik merek atau Kantor Merek yang menerima pengajuan permohonan tersebut.

b. Perlindungan Represif

Perlindungan yang represif bertujuan untuk menyelesaikan terjadinya sengketa, termasuk penangananya di lembaga peradilan (Alfons, 2010). Pada awalnya hanya terdapat satu macam sanksi, yaitu sanksi kriminal berupa hukuman dalam arti sempit terkait dengan kehidupan, kesehatan atau kepemilikan. Namun, kemudian juga muncul sanksi perdata bersamaan dengan perkembangan hukum perdata. Perbedaan antara hukum perdata dan hukum pidana adalah perbedaan karakter sanksinya. Sanksi dalam hukum perdata bertujuan untuk memberikan reparasi, sedangkan hukum pidana tujuannya adalah retributif atau menurut pandangan modern adalah adanya pencegahan (Kelsen, 1967).

Undang-Undang Nomor 20 Tahun 2016 tentang Merek dan Indikasi Geografis (UU Merek) mengatur mengenai hak pemilik merek terdaftar untuk melakukan penghapusan yang diatur dalam Pasal 72 UU Merek. Dalam hal pembatalan merek, Pasal 76 UU Merek, pihak yang berkepentingan dapat mengajukan gugatan pembatalan Merek terdaftar berdasarkan alasan dalam Pasal 20 UU Merek dalam ketentuan mengenai merek yang tidak dapat didaftarkan dan Pasal 21 UU Merek dalam ketentuan mengenai permohonan merek yang ditolak dan gugatan pembatalan ini diajukan ke Pengadilan Niaga terhadap pemilik merek terdaftar. Dalam Pasal 83 UU Merek, Gugatan atas Pelanggaran Merek dapat pula dilakukan oleh pemilik merek terdaftar dan/atau penerima Lisensi Merek terdaftar untuk mengajukan terhadap pihak lain yang secara tanpa hak menggunakan merek yang mempunyai persamaan pada pokoknya atau keseluruhannya untung barang atau jasa yang sejenis.

Terdapat pula ketentuan pidana yang diatur untuk menjaga penyalahgunaan merek. Ketentuan pidana ini dalam UU Merek diatur Pasal 100 UU Merek. Pada situasi tertentu, cara yang lebih baik dan cepat dalam hal terjadi pelanggaran merek adalah penyelesaian sengketa tersebut melalui mediasi menggunakan lembaga mediasi dimana penyelesaian sengketa melalui mediasi memiliki prosedur yang lebih singkat dan murah dibandingkan dengan proses di pengadilan, hal ini juga menjaga nama baik dari para pihak yang bersengketa sesuai dengan ketentuan dalam Pasal93 UU Merek (Wawancara dengan Arief Setiawan, 25 Oktober 2018).

Untuk menyelesaikan persoalan atau sengketa mengenai merek internasional terdapat Pusat Arbitrase dan Mediasi WIPO yang merupakan penyedia penyelesaian sengketa netral, internasional, dan nirlaba yang menawarkan opsi penyelesaian sengketa alternatif (ADR) yang hemat waktu dan biaya. Mediasi WIPO, arbitrase, arbitrasi yang dipercepat, dan penentuan ahli memungkinkan pihak 
swasta untuk menyelesaikan sengketa Informasi Publik dan teknologi domestik atau lintas batas mereka di luar pengadilan secara efisien (Lihat: http://www.wipo.int/amc/en/domains/ ).

\section{Upaya Sosiologis}

Tidak terdapat upaya berarti yang dapat dilakukan oleh Pemerintah dalam mengubah pemahaman ataupun budaya UMKM selain memberikan edukasi mengenai Protokol Madrid. Hal ini karena budaya sadar hukum hanya dapat muncul dari dalam diri pelaku usaha itu sendiri. Kurangnya wawasan UMKM yang dirasa masih kurang maksimal mengenai pendaftaran merek internasional menggunakan Protokol Madrid. Oleh karena itu, pemerintah terus melakukan sosialisasi dan advokasi mengenai Protokol Madrid.

Pemerintah memberikan pemahaman pentingnya pendaftaran merek khususnya pendaftaran merek internasional bagi UMKM, kemudahan pendaftaran merek internasional melalui Protokol Madrid, serta hak merek dan perlindungan hukum bagi pemegang hak merek atas merek yang telah didaftarkan (Wawancara dengan Rasyid Kurniawan, 3 November 2018). Namun sosialisasi ini juga masih secara umum, belum dikhususkan sosialisasi bagi pelaku UMKM (Wawancara dengan Rasyid Kurniawan, 3 November 2018).

\section{KESIMPULAN}

Berdasarkan hasil penelitian dan pembahasan sebelumnya dapat disimpulkan bahwa:

1. Hambatan terhadap permohonan pendaftaran merek secara internasional bagi UMKM setelah diterbitkan Peraturan Presiden No. 92 Tahun 2017 tentang Ratifikasi
Protokol Madrid disebabkan karena adanya hambatan sosiologis, hambatan yuridis, hambatan teknis serta hambatan ekonomis.

2. Upaya yang dilakukan pemerintah dalam menanggulangi hambatan permohonan pendaftaran merek internasional bagi UMKM setelah diterbitkan Peraturan Presiden No. 92 Tahun 2017 tentang Ratifikasi Protokol Madrid adalah upya normatif, upaya subtantif serta upaya sosiologis.

\section{DAFTAR PUSTAKA}

Adi, Rianto. (2012). Sosiologi Hukum Kajian Hukum Secara Sosiologis. Jakarta: Yayasan Obor.

Ali, Zainuddin. (2009). Metode Penelitian. Jakarta: Sinar Grafika.

Azwar, Saifuddin. (1998). Metode Penelitian. Yogyakarta : Pustaka Pelajar

Alfons, Maria. 2010. Implementasi

Perlindungan Indikasi Geografis Atas

Produk- Produk Masyarakat Lokal dalam

Perspektif Hak Kekakyaan Intelektual.

Malang: Universitas Brawijaya. p. 18.

Direktorat Jenderal Kekayaan Intelektual, "Sosialisasi Pendaftaran Merek Internasional Madrid Protokol". Desember 1, 2018. http://www.dgip.go.id/sosialisasipendaftaran-merek-internasional-madridprotoco.

Dhawy, Afif. (2018, September 25). Personal Interview.

Hartono, Sri Redjeki. 1993. Aspek Hukum Perdata Perlindungan Hak Milik Intelektual. Semarang: Program Studi Ilmu Hukum Undip. 
Hastarini, Isabella Yudha. (2018, September 28). Personal Interview.

Issetiabudi, David Eka. "Ini Dampak Protokol Madrid Bagi Konsultan \& Pemilik Merek". Maret 26, 2018. http://kabar24.bisnis.com/read/2017100 3/16/695579/ini-dampak- protokolmadrid-bagi-konsultan-pemilik-merek.

Jened, Rahmi. (2013). Hukum Merek : Trademark Law. Prenada Media.

Kelsen, Hans. (1967). Pure Theory Of Law, Translation from the Secon German Edition. Translated by : Max Knight, Berkeley, Los Angeles. London : University of California Press.

Kurniawan, Rasyid. (2018, November 3).

Personal Interview.

Kompas, "Paten Kopi Gayo Milik Belanda, Toraja Milik Jepang”. Desember 5, 2018. https://nasional.kompas.com/read/2008/ 05/28/15421243/paten. kopi. gayo. milik. belanda. toraja. Milik. jepang.

Nurhayati, Irna \& Merdekawati, Agustina. (2008). "Relevansi Keikutsertaan Indonesia Dalam International Registration of Marks Madrid System Melalui Ratifikasi Madrid Protocol Terhadap Potensi Peningkatan Daya Saing Bangsa Indonesia di Bidang Perdagangan Internasional", Mimbar Hukum, Vol.20 No. 3.

Riswandi, Budi Agus. (2018, Oktober 21).

Personal Interview.

Setiawan, Arief. (2018, Oktober 25).

Personal Interview.

Setiawan, Arief. (2018, November 27). Personal Interview.

Sumardjono \& SW, Maria. (2014).
Metodologi Penelitian Ilmu Hukum. Yogyakarta: Universitas Gadjah Mada.

Suryomurcito, Gunawan. (2007). "Accession to Madrid System Issues, Prospects and Expectations", Seminar The Madrid Protocol for International Registration of Marks the Benefits and Challenges for Indonesia, Jakarta, 24 April 2007.

Utomo, Tomi Suryo (2010). Hak Kekayaan Intelektual (HKI) di Era Global: Sebuah Kajian Kontemporer. Yogyakarta: Graha Ilmu.

UMKM Indonesia, "Sertifikat Merek". Desember 4, 2018. https://www.ukmindonesia.id/bacaartikel/95.

Waluyo, Sri Hadi. (2018, September 5).

Personal Interview.

Wuri, Lidwina . (2018, September 21). Personal Interview.

World Intelectual Property Organization. Oktober 29, 2018. http:// www. wipo. int/ finance/ en/madrid. Html.

World Intelectual Property Organization Oktober 29, 2018. http://www. wipo.int/amc/en/domains/.

Kumparan, "UKM Daftarkan Merek Lewat Sistem Protokol Madrid Masih Sunyi". Desember 4, 2018. https://kumparan.com/media-centerkementerian-hukum-dan-ham/ukmdaftarkan-merek-ke-luar-negeri-sistemprotokol-madrid-masih-sunyi 27431110790549847.

Yudistira, Andra Bayu. BEKRAF, "Penandatanganan Perjanjian Kerja Sama Badan Ekonomi Kreatif (Bekraf) dengan Lembaga Pengelola Dana Bergulir - 
Koperasi dan Usaha Mikro, Kecil dan Menengah (LPDB - KUMKM). Desember 4, 2018.

http://www.bekraf.go.id/berita/page/10/ 76-penandatanganan-perjanjian-kerjasama-badan-ekonomi-kreatif-bekrafdengan-lembaga-pengelola-dana- bergulirkoperasi-dan-usaha-mikro-kecil-danmenengah-lpdb-kumkm. 